\title{
Internalization of Intrinsic Value of Trust in Financial Accountability: A Study of Subak Jatiluwih Bali Indonesia
}

\author{
I Gede Sanica $^{1}$, Luh Putu Wiagustini ${ }^{2}$, I.B Panji Sedana ${ }^{2} \&$ Ni Luh Gede Sri Artini ${ }^{2}$ \\ ${ }^{1}$ Faculty of Economic and Business, Universitas Pendidikan Nasional, Bali, Indonesia \\ ${ }^{2}$ Faculty of Economic and Business, Udayana University, Bali, Indonesia \\ Correspondence: I Gede Sanica, Faculty of Economic and Business, Universitas Pendidikan Nasional, Bali, \\ Indonesia. E-mail: gede_sanica@yahoo.com
}

Received: October 31, 2018

Accepted: December 21, 2018

Online Published: December 24, 2018

doi:10.5539/ibr.v12n1p99

URL: https://doi.org/10.5539/ibr.v12n1p99

\begin{abstract}
The objective of this research is to disclose more deeply the influence of the intrinsic elements, namely, trust in the financial accountability of Subak Jatiluwih. This research applied ethno-methodological method seeking to understand and capture phenomenon through observations in the form of non-quantitative data and observing the phenomenon until the real truth is revealed. Validation and legality of data in qualitative research was carried out using triangulation techniques. The results of the study show a new paradigm in financial accountability as in the triple bottom line that the reporting of organizational performance is not just reporting financial transactions but also integrating social and natural environment. This is in line with the principles of Tri Hita Karana recognizing three elements namely parhyangan, pawongan and palemahan which aim at forming harmonization, harmony and togetherness, as an integral and inseparable unit. Trust is the most important element in the social system because the behavior of members in society is strongly influenced by what they believe and what is known as the truth, religious system and the ways of worshiping God Almighty. Trust is a statement about things that are accepted as genuine truth that are used as guidelines for activities to achieve a goal. Elements of trust oriented to traditional values in Subak are realized in various religious ceremonies. The substance of trust in Subak is not only related to trust in Subak management or bonding concept, but also trust with other stakeholders through bridging and linking in social capital concept.
\end{abstract}

Keywords: trust, social capital, Tri Hita Karana, financial accountability

\section{JEL Classification: Z13; O17; Z12; M41}

\section{Introduction}

Subak is a social organization that plays a role in the management of traditional irrigation systems in Bali Province, Indonesia. The existence of Subak has been going on for decades because of its uniqueness in integrating socio-agrarian-religious elements. Subak Jatiluwih is one of the Subaks in Bali Province which has been designated as a World Cultural Heritage by World Heritage Committee of UNESCO on June 29, 2012 at St. Petersburg, Russian Federation as a Cultural Landscape of Bali Province: the Subak System as a Manifestation of the Tri Hita Karana Philosophy. Tri Hita Karana recognizing three elements namely human relations with God (Parhyangan), human relations with humans (Pawongan) and human relations with nature (Palemahan). It has implications on increasing the welfare of community both economically and socio-culturally.

As an organization, in carrying out activities, Subak passes through stages from planning to evaluation. Financial accountability is also one of the important parts in the management of Subak organization. Good organizational management is commonly called as Good Corporate Governance (GCG) which contains aspects of accountability, responsibility, independency, transparency and fairness. One of the important aspects of good governance seen from the aspect of accountability includes various other aspects in the application of the GCG concept.

In the religious perspective, accountability is related to the element of trust which is universal and has existed earlier than the agency concept so that the concept of accountability can be said to be a metamorphosis of trust (Triyuwono, 2009). This trust concept has given prominent effect in management formulations and accounting ideas and practices because trust to the creator encourages good accounting practices, therefore the financial 
statement is not only for the benefit of the world but also for spiritual action. In the spiritual realm, accounting and accountability leads to the call of conscience and spirituality so the essence of accountability leads to morality based on the principles of honesty, empathy and love that arise implicitly from one's conscience.

Financial accountability based on the religious aspect cannot be separated from the role of social capital built in the management of the organization. Lewandowski (2006) states that social capital is a communal inventory of generalized trust and social norms bridging a cooperative action. According to Putnam (1993), the concept of social capital leads to a moral bonding function, namely the norm that applies in society in relation to transcendental or spiritual capital that is automatically formed in the concept of social culture and the affirmation of intrinsic value of the capital concept. In a social capital there are constituent elements including bonding, bridging and linking which mutually synergize to form a unity. A group with a strong bonding tends to ignore the external environment so as to neutralize and complement, it is necessary to exist the role of bridging and linking in building the integration of a system interaction that is beneficial for the whole community (Halpern, 2005).

Subak is a social organization developing traditionally according to customary law which has a different uniqueness from other organizations. In addition to be a peasant irrigation organization, Subak also has material and immaterial capital (Sutha, 1978: 7). This socio-agrarian-religious value integration has become a unique feature of Subak's organizational governance. Subak emphasizing the principle of Tri Hita Karana contains three important components of life in Hindu teachings, namely human relations with God (Parhyangan), human relations with humans (Pawongan) and human relations with nature (Palemahan). Spiritual capital in Subak is contained in the philosophy and religious ritual activities carried out by its member farmers so that this spiritual capital becomes a unique local cultural value in Subak organization. This activity is a reflection of effort to maintain harmony between Subak members and the Creator, nature and members. Harmonization of relations with God (Parhyangan) is shown by holy buildings such as temples to perform their traditional ceremonies or rituals. While the harmonization of pawongan is reflected in the relationships between members while harmonizing with the natural environment (palemahan) is indicated by a sense of care and responsibility to environmental sustainability.

Different from the organizations having profit oriented as well as other social ones, the existence of Subak Jatiluwih has its own uniqueness in integrating various intrinsic elements in financial accountability than conventional accountability which is only focusing merely on financial reporting in writing. This study aims at revealing more deeply the influence of intrinsic elements, namely trust in financial accountability of Subak Jatiluwih.

\section{Literature Review}

According to the conventional view of accounting information is a set of actions that contain information that acts as a reflection or description of the factual and objective recording that occurs in an organization in a certain period (Roberts and Scapens, 1985). Theoretically, accountability does not yet have a patent definition. The concept of accountability arises as a result of functional gaps in an organization therefore evaluation is necessary (Erdogan et al., 2004) and that corporate elements understand and believe that something has been well done (Vamosi, 2005).Accountability practices in a business can provide benefits to increase transparency, improve the quality of decisions and clarify responsibilities for organizational roles (Beckett, 2002). Accountability is the main principle in creating GCG including in the management of natural resources so that it can mitigate the negative impacts on the environment and maintain environmental sustainability (Ottinger, 1968; Koppel, 2005; Bovens, 2007). In this context, accountability is not only limited to conventional economic aspects but also has integrated social aspects, environment leading to sustainability accounting (Perera and Mathews, 1997) or the so-called triple bottom line accounting (Lüdeke, et al, 2011). An organization or company must also have external support to help run financial management and financial funding sources in the form of investment or credit (Guo, 2017). On the other side, the concept of accountability can also integrate the role of spiritual capital by incorporating elements of trust as a complement to accountability practices. Spiritual capital (spiritual capital) has a significant influence on the style of the Board of Directors (BOD) and the way they manage the organization both in terms of capital owners and implementers (Shamsuddin, et al. 2016). So that the concept of accountability in practice can be integrated values outside the economic elements such as spiritual, social, cultural, environmental and so on.

This concept of accountability does not only look at the perspective of accountability from an economic standpoint, but also from various aspects related to social. The concept of accountability combined with cultural, spiritual and social elements usually occurs in groups of people who are as unique as Balinese people who are very close to these elements. Similarly, Subak organization is one of the non-profit organizations integrating the 
concept of Tri Hita Karana. In this concept, the behavior of Subak's agency uphold the element of trust in carrying out organizational practices from all its governance systems. Trust has emerged as an important problem in business accountability since people have become critical on the business values recently. According to Glover (1995) that commercial interactions are observed and tried to be detected further and critically because most people find market morality has no correlation with people's behavior. This belief theory arises due to the dynamics of human behavior that cannot be continuously predicted so that the element of trust between agents is also likely to experience a shift. The belief theory as the element of strengthening the organization accountability arises as an expectation that the actions of agents in a community, organization or institution will provide more benefits than losses (Gambetta, 1988). This trust is one of the important instruments in the market mechanism so that it will create the expected balance (Bhati, 2015) .This belief theory plays an important role in an organization because it is considered to be able to organize and direct agent behavior in order that society will function better. Ericson (1968) considered that trust is the center of a healthy personality element which in itself will create harmony leading to norms of goodness. So this element of trust provides a strong credit to the organization accountability.

Some empirical studies on financial accountability including intrinsic value, such as carried out by Fikri (2010) on organizations concern on environment, namely WWF ( World Wide for Nature ). The result of the study indicated that WWF has two forms of formal accountability, namely financial accountability and program accountability. In addition, the organization also carries out non-formal accountability, namely action accountability to community. Action accountability taken by WWF organizations are based on good intentions and obligations. While Randa (2011) was in non-governmental organization , one of the churches influenced by Toraja culture. The result of the study by Randa (2011) shows that the practice of accountability carried out in the church is inseparable from the original religion of Toraja people called alukta. The practice of accountability is influenced by the values believed by Toraja community. The values affecting the accountability practice are transcendent, namely the relationship with the creator, relationship with fellow creatures, and relationship with the universe. These three dimensions can be found in the traditional community organization of Toraja called tongkonan as the center of community activity. Dewi (2008) on accountability in profit-seeking organizations, namely the Village Credit Institutions (LPD) in Bali, shows that the accountability carried out is influenced by the cultural values existing in the LPD. This value is the concept of Tri Hita Karana, namely accountability practices conducted by LPD not only to fellow human beings (pawongan), but also forms of accountability practices to the environment (palemahan) and to God (parahyangan).

\section{Method}

The concept of accountability arises as a result of functional gaps in an organization therefore evaluation is necessary (Erdogan et al. , 2004) and that corporate elements understand and believe that something has been well done (Vamosi, 2005).Accountability practices in a business can provide benefits to increase transparency, improve the quality of decisions and clarify responsibilities for organizational roles (Beckett, 2002). Accountability is the main principle in creating GCG including in the management of natural resources so that it can mitigate the negative impacts on the environment and maintain environmental sustainability (Ottinger, 1968; Koppel, 2005; Bovens, 2007). In this context, accountability is not only limited to conventional economic aspects but also has integrated social aspects, environment leading to sustainability accounting (Perera and Mathews, 1997) or the so-called triple bottom line accounting (Lüdeke, et al, 2011). To explore deeply related to accountability applied in Subak organizations, this research uses ethnometodology methods. According to Neuman (1997) ethnometodology presents the reality of levels more than sociology so that it differs from sociology and psychology. Ethnometodology limits include review of observations of creation that are used continuously in social interactions with the environment. In terms of terminology, ethnometodology is a method of organizing society by looking at several aspects of need, namely enlightenment and empowerment. Ethnometodology seeks to understand how people begin to see, explain, and describe the order of the world in which they live. The use of this method is motivated more by practical thinking compared to the benefits of formal logic. Ethnometodology researchers seem to be good partisans, honest writers, and friendly facilitators. Academic logic possessed by researchers in ethnometodology will be tested by inter-subject experience in the dialogue process so that academic logic will blend with the common sense of the local community. The term ethnometodology was introduced by Harold Garfinkel in the mid 1950s as an inspiration for the creation of phenomenology sociology. The ethnometodology concept by Garfinkel is the development of the phenomenology study of Alfred Schutz at the New School for Social Research where the everyday world is an inter subjective world which is a daily social reality and becomes common sense and ignores doubts. Social reality is a cultural object and a social institution in which all are born, know each other, relate from the 
beginning, and live the world as a world of culture as well as the natural world. In ethnometodology, researchers who come from outside the environment must be able to unite and be directly involved in the research process together with social actors in a society. Researchers must be able to merge into the community being studied, and must be able to be together with the community studied in a complex social interaction.

\section{Results}

\subsection{The Value of Trust in Accountability}

The concept of this trust theory is the result of reconstruction of theoretical and social practices including the basis, interpersonal trust, personal trust, general interpersonal trust and interpersonal trust in the internal sphere. Trust can be defined as a social universal phenomenon and a social capacity obtained from social processes. Some characteristics of trust include basic trust or ontological security (Giddens 1990) that is a trust having a strong bonding to the human in person. Interpersonal trust develops on the foundation of basic trust, the capacity to depend on oneself, others and the world, in the next socialization phase, by integrating the normative dimension of social relationship rules as a form of implementation of human nature as social beings or homo sociologicus (Seligman 1997). The form of community interpersonal trust can be reflected in unconditional nature of loyalty aimed at kinship or family relationships (Putnam, 1993). Loyalty is formed unconditionally so that it raises honesty and high solidarity in maintaining a social relationship. While people with low levels of trust will create a strong primordial element that will create vulnerability to a group conflict (Füzér, 2016)

In Subak organization, this element of trust has been strongly built with the integration to the Tri Hita Karana concept. The role of this trust element can be reflected in the rituals performed as a form of devotion and obedience to God Almighty and is believed to bring benefits to their lives. In addition, horizontal trust is also reflected in the inter-community behavior in the distribution of irrigation that has been mutually and fairly agreed early so that it will not harm other parties or farmers. In terms of Subak's financial accountability, this trust element can be reflected in the management and reporting of activities and the results of use of funds that are openly conveyed and can be accepted by all elements both Subak members and external parties such as the Government of Bali Provincial and Tabanan Regency.

The implementation of financial management and accountability is an important practice carried out by an organization both business and non-profit. The problems of financial management and accountability occurring in organizations basically arise because of the desire to be selfish and not to provide the information that should be of interest to the parties concerned. This also occurs in non-profit organizations, namely Subak which consists of farmers or customary law communities having socio-agrarian-religious characteristics. Several empirical studies have shown the important role of religious structures in Subak irrigation systems. This religious study was shown by the existence of one or more Bedugul Temple (to worship Dewi Sri as the manifestation of God as the Goddess of fertility), in addition to the existence of sanggah pecatu (sacred buildings) placed around the intake building in each block / farmer's rice field complex of Subak members. The religious performances on Subak irrigation systems are a reflection of Tri Hita Karana (THK) concept which essentially consists of parhyangan, palemahan, and pawongan (Sutawan, 1983). This shows that the implementation of this trust element in God plays a strong role in Subak organization.

Subak is a non-profit community organization engaged in agriculture and has a major role in managing irrigation of farmers' rice fields, in addition to as a unique asset having local wisdom values of Balinese culture. The emergence of Subak departs from the philosophical meaning of Tri Hita Karana concept which emphasizes the principle of vertical and horizontal accountability in managing rice fields. Vertically it is intended for the Creator (God) and horizontally it is aimed at the environment and fellow human beings. In some studies, the principle of Tri Hita Karana has become a strong element in the existence of Subak for centuries.

The concept of Tri Hita Karana is a concept of local cultural values that has grown in the tradition of Balinese society, and even today it has become the philosophical foundation of business, tourism development, spatial arrangement, and regional development strategic plan. The concept of life emphasizes the principles of togetherness, harmony and balance between economic goals, environmental and cultural preservation, aesthetics and spirituality (Tenaya, 2007; Saputra et al, 2018). The dynamic nature of Tri Hita Karana is in line with the socio-economic dynamics of community and as a unified cultural system that is also a strong foundation in running an organization's business both profit and social. As with Subak as an organization, business management process, including finance, is also based on the concept of accountability or responsibility in THK. THK's religious concept is able to create humans to be responsible in life of the universe. This concept of Tri Hita Karana carries several sub-concepts which also result from a mixture of social and spiritual elements. If these concepts are synergized will become one in Tri Hita Karana consisting of Parhyangan, Pawongan, and Palemahan. 
Parhyangan is the concept of harmony between humans and God Almighty, in this case the behavior of Subak members will be controlled by devotion to the Almighty God so that they do not commit acts violating the spiritual teachings or are not subject to the law of act or known as the law of karma phala. The essence of Tri Hita Karana's teachings is harmony and cooperation as its philosophical foundation stated in the Vedas. Parhyangan is an integrity that has spiritual element, highly dedicated and upholds honesty in the form of spiritual accountability to God Almighty. Accountability in this context includes spiritual accountability based on the individual's relationship with God, and is only known and understood by the person concerned. Spiritual accountability is abstract in the form of faith (sraddha) and piety (bhakti) to God. Every activity of community or organization is always indicated by the symbol of the existence of temple as a form of belief and devotion to the Almighty God. Pura (temple) is not only seen as a building of ordinary artifacts, but a temple also functions as a spiritual control of Subak members' behavior.

The following is the statement of INS informant:

..."THK misal semua warga negara Indonesia percaya pada Tuhan Yang Maha Esa. Kalo misal di Bali termasuk di Jatiluwih terkait dengan THK, pada saat kita menjelang mau tanam padi, menjelang ke sawah ya ada istilah upacara jemput air tapi dengan ritual, setelah dijemput diatur sedemikian rupa. Setelah diatur kan tidak terjadi permasalahan si A dapet berapa si B dapet berapa. Itu kalau bahasa balinya medhak tuyu. Setelah diatur sedemikian rupa sesuai hak nya, masuk ke sawah kemudian cangkul pertama mendaghir namanya ada ritual sampai padi naik atau turun ke lumbung ada ritual. Misalnya kalau ada padi berumur 2,5 bulan terutama padi lokal itu adanya namanya ritual nengluk merane, artinya kita mengendalikan hama dengan ritual, sembayangnya dimana, pekendungan, tanah lot, puri tabanan. Air itu dicampur jadi satu air suci itu,setelah itu disprosisi ke peruk besah dan bedugul. Disprosisi kesana lagi dan dibawah ke bedugul masing-masing. Kan ada tujuh bedugul. Disposisilah disana setelah dari sana barulah masing-masing kepemilikan sawah dibersih-bersihkan ada ritualnya juga. Itu kan budaya dan agama juga."..."kalau manusia dengan manusia diatur dalam awig-awig diatur dalam pawongannya."..."itu sangat kuat sekali itu namanya pawongan.

... "THK, for example, all Indonesian citizens believe in God Almighty. In Bali, including in Jatiluwih, for example, in relation to THK, by planting rice, or when we are going to the rice field, there is a term of ceremony for picking up water but it is performed with a ritual, after it is picked up it is managed in such a way. After it is arranged, there will be no problem regarding how many A can get, and how many B can get. In Balinese language it is called medhak tuyu. After being arranged in such a way according to its rights, entering the rice field, then the first hoe is called as mendaghir, ritual is performed until the rice put in or out of the barn. For instance, when the rice is 2.5 months, particularly local rice, there is a ritual called nengluk merane, meaning that we control pests with rituals, the prayer takes place at Pekendungan, Tanah Lot, Tabanan Palace. The water is mixed together into one holy water, after that procession is conducted to peruk besah and bedugul. Then the procession is conducted there again and brought to each bedugul. There are seven bedugul. The procession is conducted there and from there each rice field is cleared and there is a ritual as well. It is a culture and also religion. "..." if humans and humans are regulated in awig-awig, they are arranged in their groups. "..." it is very strong, it is called pawongan.

In the financial accountability report, the majority of the Subak's financial budget is used for religious ceremonies and temple buildings. The implementation of spiritual values in Subak organization is demonstrated through various rituals carried out during the planting process from before planting to post harvest. Every ritual or ceremony carried out has its own purpose and meaning addressed to the Creator. The following are some of the rituals of religious ceremonies as symbolic of the worship of God performed by the people of Jatiluwih during the period before planting to post-harvest:

1. Mapag Toya ritual to pick up water which later will be organized by Tempek management to manage the source of irrigation in each rice field. This ritual is addressed to God Wisnu with the aim that the water source is smooth so that the process of drainage or irrigation during the planting period also flows smooth.

2. Ngedangin ritual is carried out after seedling seed and is carried out when processing and irrigating the fields before planting the seedlings that have been sown.

3. Ngurit Pengiwit ritual is held immediately before sowing the seeds in the rice fields. With the aim at requesting that the sowing seeds grow well.

4. Nandur ritual aims at welcoming the transfer of seedlings from the seedlings to each plot of the rice field and in order that the seedlings planted may grow well until harvest. 
5. Ngeroras, Mubuhin and Neduh/Ngebulahin rituals. This ritual is held to welcome the age of rice after 12.15 and 25 days with the aim that rice can grow well.

6. Nyambuti and Biukukung ritual aims at welcoming the age of 42 days and 70 days of seedlings that have been moved to the plot of rice field and pray to God for the rice plants to avoid pest attacks so that rice can grow with good yields.

7. Ngerestiti ritual is a ritual that is carried out when the rice is attacked by a pest. This ritual is addressed to God in order that the pests do not damage rice plants.

8. Nyungsung ritual is to welcome the rice grains starting to grow.

9. Ngusaba ritual for the purpose of pleading to God so that the harvest will be done without any obstacles and get good proceeds.

10. Nyangket ritual is aimed that the harvesting process to be run smoothly.

11. Ngerasakin ritual is performed as a token of gratitude to God that the harvest has run well as expected.

12. Mantenin ritual is to show gratitude to God and to thank Dewi Sri for the gifts given to the farmers and for Dewi Sri to always guard and stay in the rice stored in the barn.

These various rituals as a form of obedience and belief of peasant community in Jatiluwih Village Tabanan Bali to the power of God so that the planting process until harvest goes well. These rituals become a component in Subak that cannot be separated since the spiritual power is believed to bring to good things. Parhyangan teaches a culture of honesty or accountability, open and helps each other and eliminates actions that harm others and nature. Spiritual capital in the element of Tri Hita Karana is able to create harmonization due to mutual trust between farmers who are always maintained all this time. This trust is firmly attached that's why it can maintain the continuity of Subak for centuries. Farmers in Subak will not commit irregularities that can harm others because they believe in the law of karma phala as one of the spiritual laws when a person commits a offence. Their high belief in the power of God is able to make a positive contribution in maintaining the sustainability and continuity of Subak Jatiluwih through accountability in financial reporting and governance in Subak organization.

\subsection{Social Capital Integration in Accountability}

The form of accountability integrating the intrinsic elements of social and spiritual capital in Tri Hita Karana concept is also carried out through the harmony of human relations with humans ( pawongan ).As God's creatures, maintaining harmony with fellow human beings internally within the organization as well as externally can mitigate conflicts. Harmony can be achieved through harmonious cooperation with fellow human beings who are driven by uncertainty, limitations and scarcity of resources owned by humans so that social relations become an absoluteness (Windia and Dewi, 2011). Some of the core teachings in Hinduism describing harmony are Tri Kaya Parisudha or three good deeds involving manacika or mindset, wacika or words and kayika or behavior and the process of Tri Kaya Parisudha is a gift which means that humans have done good deeds and have caused harmony among their fellows.This Pawongan is closely related to the element of social capital which is reflected in the nature of mutual cooperation and traditions that are strongly attached to Balinese society in general.

In an organization including Subak in Jatiluwih has a rule of game or institutional rule that becomes the rules for all elements in synergy in carrying out activities. In the institutional concept, it is known three terms of social capitals. Social capital is a concept that encompasses all elements of social norms and networks as a medium of cooperation between individuals and amongst individual groups (Putnam, 1993, Grafton, 2005; Nunko, 2017). The concept is firmly embedded in social processes and relationships that involve feelings, and other inner elements so that collaboration in compliance with development goal is created. The application in the institutional concept also cannot be separated from spiritual capital which is synergized with the elements of Balinese public trust to their religion which is very strong in each individual.

In social capital there are three elements that are strongly attached to form a strong social capital and maintain the continuity of social relations within an organization namely bonding, bridging and linking (Woolkock \& Narayan, 2002) .This form of bonding or relationship among members of Subak Jatiluwih is shown by the synergy among members in cooperation to achieve the goal of members' welfare. One of the strong harmonization of social relationship bonding in Subak Jatiluwih organization is shown when there are rituals or traditional ceremonies. Through these activities, solidarity and strong cooperation between communities is created. When the ceremonial procession is conducted, all members in each place held rituals, some are 
individuals in their respective fields and some are together in a temple like Bedugul temple or in the land plot. This togetherness turns out to be able to create a high social emotional bond and can create harmonization of cooperation within an organization. In addition, the form of bonding found in Subak Jatiluwih organization is also seen when there are rice management events ranging from water management to harvesting.

Accountability or financial accountability in the principle of bridging and guarding is more concerned with the creation of quality compared to quantity. The creation of bridging in financial accountability provides more positive values at the macro level, especially the trust of external parties. In contrast to bonding which strengthens internal harmony but excludes other groups. While bridging is more on creating trust and social networks with other groups so as to provide positive feedback on the existence of Subak Jatiluwih. The concept of bridging in the elements of Subak Jatiluwih pawongan shows a dynamic nature in response to the socio-economic dynamics of the community, Subak is a religious social organization which is also outward looking towards the surrounding external environment, but still in the corridor upholding the values of Tri Hita Karana.

Other element of social capital that has a prominent role in Subak is linking which is a vertical relationship between Subak officials and other communities outside Subak, for example, the government and private sector. Sources of funds that are dominated by provincial funds in the form of Bantuan Keuangan Khusus (BKK) or special financial assistance and funds from tourism services in the form of Daya Tarik Wisata (DTW) or tourist attraction funds are one of the forms of funding occurred after Subak Jatiluwih included in the world cultural heritage site of UNESCO in 2012. From here, there were several sources of funding inputs, such as from tourism office and Bali Provincial Government as described by informant INA as follows.

"ya, masih ada hubungannya dengan pemda pemerintah daerah, dinas pariwisata itu ada dana masuk, kalau setiap bulannya kalau sekarang ya rata-rata 25 juta lah per bulan. Kalau dari propinsi ada dana BKK 50juta masuk ke pekaseh. Itu rutin kemudian dana itu cuman diambil aja ditarik aja oleh pekaseh dan diecerkan ke tempek-tempek ini. Dan bergilir setiap tahunnya. Dan pertanggungjawabannya subak pengguna disini cuman dia menyiapkan kuitansi untuk apa misalnya nota dan sebagainya kita serahkan ke pekaseh dan pekaseh ke desa, desa membuat pertanggungjawaban ke pemerintah".

"Yes, there are still something to do with the regional government, tourism agency, there are funds coming in, every month it is now about 25 million average. From the province there are 50 million of BKK funds going into Pekaseh (Head of Subak). It was routine, then the funds is taken or withdrawn by Pekaseh and then is distributed to tempek (sub-group members). And take turns every year. And the responsibility is that Subak users only prepare receipts for what, for example, notes and so on, we submit it to Pekaseh and fromPekaseh to village offices, the village makes accountability to the government".

Judging from the linking element between Subak and the government, it is closely intertwined through development activities. This happens because government integration related to Subak infrastructure development is also routinely carried out through the flow of source of funds obtained every year. In terms of applicability, the use of funds from the government, for example from DTW funds, this is used for ritual activities which are indeed the characteristics or local wisdom of Balinese people in general. In addition, the remaining funds are also used for minor infrastructure improvements. About $21 \%$ of these DTW funds were handed over to Subak, which was then divided into 7 locations, each of which received funds of 3\% each month. In addition to DTW, there are also other revenue sources from the government called Special Financial Assistance (BKK) from Bali Provincial Government. The form of assistance was allocated for the manufacture and repair of Subak infrastructure and places of worship such as temples, roads, bridges and irrigation channels as disclosed by informant INA:

"Kalau dari propinsi ada dana BKK 50 juta masuk ke pekaseh. Itu rutin kemudian dana itu cuman diambil aja ditarik aja oleh pekaseh dan diecerkan ke tempek-tempek ini. Dan bergilir setiap tahunnya. Dibawah kerjasama desa bersama pemda, nah dari itung-itungan itu Subak mendapat 21\% untuk seluruh Subak, berarti masing2 tempek mendapat $3 \%$ itu dikelola masing 2 tempek. Terus sampai sekarang astungkare tidak pernah kurang"

"If there are 50 million BKK funds from the province, it is addressed to Pekaseh. It was routine, then the funds is taken or withdrawn by Pekaseh and then is distributed to tempek (sub-group members). And take turns every year. Under the village cooperation with the local government, Subak has received 21\% of all Subak of the area, meaning that sub-group obtains $3 \%$ managed by each sub-group. And until now, astungkare (thanks God) no shortage at all"

The form of linking that exists between Subak and the government also does not run well and optimally as there are also some problems, for example, related to the construction of bridges or other infrastructure that did not run 
according to standard so that they are faster damage is disclosed by INA:

"Masalahnya kalau pekerjaan dikerjakan oleh pemerintah mungkin bagaimana pengawasannya, kadang2 kualitas proyek dipertanyakan. ya mengeluh, dampaknya kan mengeluh kok baru setahun udah jebol. Kalo proyek swakelola atau swakarya dikelola oleh desa gak sampai gitu"

"The problem is that if the work done by the government, perhaps how it was supervised, sometimes the quality of the project is questioned. yes complaint, the impact of complaining is that how come it is just one year but it has broken. If the project is self-managed or self-supported, where it is managed by the village, it never happens?"

From these conditions, it is indicated that there is a need for stronger supervision and work control so as not to create possible problems. On the other hand, the relationship between Subak and superior government institutions (Sedahan), Sedahan Agung, and the Regent/Mayor, Chief of the Region having structural relations, especially in the imposition of Land and Building Tax, but it must be associated with orders to increase agricultural production in Subak. The relation of Subak to the same level institutions, such as village, traditional village, and kelurahan realized in the form of coordination with: 1) Public Works Department Subak Irrigation Section planning, building and maintaining irrigation facilities and in the form of determining water discharge, supervision of irrigation buildings, and contribution of educated manpower in the field of irrigation; 2) Agriculture Service which provides assistance in the form of developing new technologies such as the use of superior seeds, eradicating pests, fertilizing and marketing of products, up to providing contribution or loans of agricultural equipment; 3) Regional Revenue Service Payment of Subak's Land and Building Tax is carried out through Subak administrators in collaboration with Tax Agencies.

\subsection{Natural Environment Sustainability Integration in Accountability}

From the concept of Palemahan (the relationship between humans and nature), it can be reflected in the management of rice fields and irrigation which has also been regulated in awig-awig mutually agreed upon by all Subak members and local governments. The agricultural system in Bali Province is unique compared to other regions in Indonesia which does not only pay attention to the physical agricultural system but also non-physical (metaphysical agriculture). It is also inseparable from the belief of the public's belief in the power of THK concept that when humans do good to nature and the surrounding environment, nature will also respond well. The metaphysical manifestations of agriculture in Bali (Kardi, 2005) such as agricultural ceremonial ritual which is ageng (big) in nature is organized by Subak traditional social organization, such as, Nyapah ritual held in Villahe Temple (Bale Agung), and Ngusabha conducted in Beraban Subak Temple twice a year. The madya (medium) ritual, as well as niste (small) are performed by each Subak member (Krama Subak). This ceremony is carried out with the purpose of harmonizing and synergizing human relations with nature in order to create harmony. In addition, agricultural practices based on Rwa Bhineda teachings originating in the Vedic scriptures, namely cultivation activities, both on dry land and in wetlands always try to totally maintain the balance of the ecosystem. The agricultural activities currently with organic-based methods are in compliance with the teachings of Rwa Bhineda.

Muhadjir's study (2000) also supports this argument that the order of universe is in the transcendent plain which has been regulated by Al Khalik, the Creator.The balance in the universe is a proof of the power of God, the Creator. The pair of two naturally objective events in the Vedic language is called Rwa Bhineda, that is, two things that appear to be contradictory, occur in order to achieve a balance of the universe and life. Meanwhile, according to Popper (1983), metaphysical meaning is the truth stated in an untestable statement where every event has a cause which is an untestable universal existential statement. Universal events and universal causes are called metaphysical objective truths, which are untestable.

The following is the statement of INS informant:

Kalo pelemahannya mengatur sawahnya masing-masing kapan ditanam kapan panen dan sebagainya. Sehingga dengan demikian pemerintah mulai 2011,2002, 2003 sudah melakukan penelitian di Jatiluwih untuk apa, agar subak jatiluwih diusulkan ke UNESCO. Nah tahun 2004 sudah masuk nominasi namun kurang luas, karena kurang luas kembali ke revisi usulan itu untuk menambah luas,dari satu subak skrg yang diakui unesco ada 14 Subak. yang disebut dengan subak. Sehingga thn 2012 resminya diakui UNESCO. Kenapa diakui oleh unesco karena terkadung nilai-nilai yang universal, nilai-nilai yang sangat luar biasa kearifan lokal."

Palemahan governs the rice fields when to cultivate, when to harvest and so forth. Therefore, the government since 2011, 2002, 2003 had performed researches in Jatiluwih, what for, in order that Subak Jatiluwih is proposed to UNESCO. Well, in 2004 it was nominated but not broad enough, because it was not broad enough to 
revise the proposal to increase the area, from one Subak now recognized by UNESCO, there were 14 Subaks referred to Subak. So, in 2012 it was officially recognized by UNESCO. Why it is acknowledged by UNESCO because it has universal values, local wisdom that is very extraordinary."

The statement that every incident has a cause is believed to be the law of karma phala by Hindu people in Bali including farmers.Good deeds (subha karma) will result in good results. Bad deeds (asubha karma) will result in bad results. Activities carried out on farming area, of course, have the effect of harming or hurting other creatures (asubha karma), for example killing pests and plant diseases. Tat twam asi (that is me), and Advesta Sarwa Bhutanam (do not harm every creature) is a Vedic message that was originally believed and practiced by farmers in Bali. This is according to the statement of INS informant as follows:

..."misalnya gimana ya. Kalau misalnya si A melanggar kena karma pala. Kena sanksinya misal."

... "for example, what should I say. For example, A committing a breach is imposed with karma phala. Charge with sanctions, for instance."

Farmers believe that the accumulation of the remaining painful deeds will lead to universal events that can bring nature strikes back. Through the series of rituals carried out, the farmers worship to God (Idha Sang Hyang Widhi Wasa) in order that the disaster would not occur (Kardi, 2005).Sustainable agricultural development is a farming system viewed holistically (holistic approach), economically profitable (environmentally sound), in accordance with local culture and can be applied by the community (technically and culturally appropriate), and socially acceptable. The aim of sustainable agriculture is to improve the quality of life.

The land and water management system in Jatiluwih is still traditionally done by using cattle and is believed to produce better yields without interaction with chemicals. Therefore, Jatiluwih rice production is very popular with "sandalwood" brown rice or a type of "lambe gangsar barak cename" type of rice which has low glucose levels, rich in nutrients and has a distinctive scent that is not shared by other regions. The regional government issued a program of "Gerbang Pangan Serasi (Harmonious Food Gate)" (GPS) in 2015 in an area of 45 hectares, in 2016-2017 in an area of 65 hectares and in 2017-2018 increasing by 84 hectares in the form of seeds and organic fertilizer. The cultural uniqueness in cropping pattern in the village of Jatiluwih is closely related to the Nyepi day which aims at regulating the balance of ecosystem without carrying out any activities in the rice fields during Nyepi day, namely 1) when the rice reaches the age of 1.5 months to 2 months, pemungkah for 3 days; 2) the rice reaches is 2.5 months to 3 months for 2 days; and 3) at the age of rice for almost 5 months for one day.

The Cultivation patterns in Jatiluwih village use Kerta Masa cultivation pattern (a periodic cropping pattern system) which functions to suppress or break the life cycle of pests and plant diseases, while avoiding the cultivating rice in tulak sumur system (cultivation not at the time). Regulating land use with a terracing system so that the land which is used to be mountainous becomes an expanse of terraced rice fields or sengkedan that can support landslides. Gegadon - the rotation of rice plants with secondary crops due to changes in the use of water by neighboring Subak. Organizing water distribution with temuku (distribution system) consisting of temuku aya, namely water distribution in the upstream, temuku gede, that is, the size of water distribution for parts of Subak area, temuku penasan, namely, water distribution directly to the plots of rice fields, in which the number of rice farmers is approximately 10 parts and temuku penyacah, namely, the size of water distribution for individuals.

This water management has also been regulated in awig-awig according to the needs of farmers so the distribution is fairly carried out. The water distribution to the plot of rice field is according to the amount of ayahan (services) or distribution of seeds (wit). One ayahan (service) is the same as one wit tenah, that is, seeds weighing approximately of $25 \mathrm{~kg}$ get one unit of water. One unit is the same as tektek and the same as kecoran (debit), that is, a unit of water distribution calculated based on the number of ayahan (service). One tektek is the same as four fingers. This system is generally applied for the distribution of water to the rice fields. Sutawan (1989) states that Subak irrigation systems are closely related to Subak functions. There are five Subak functions, namely, search and distribution of irrigation water, conflict management, operation and maintenance of irrigation channels, religious ritual ceremonies and resource mobilization.

\section{Conclusion}

The new paradigm in financial accountability as in the triple bottom line stated that reporting organizational performance is not merely reporting financial transactions but also integrating social and natural environment. This is in line with the principles of Tri Hita Karana recognizing three elements namely parhyangan, pawongan and palemahan which aim at forming harmonization, harmony and togetherness, as an integral and inseparable unit.

Trust is the most important element in the social system because the behavior of members in society is strongly 
influenced by what they believe and what is known as the truth, religious system and the ways of worshiping God Almighty. Trust is a statement about things that are accepted as genuine truth that are used as guidelines for activities to achieve a goal. Elements of trust oriented to traditional values in Subak are realized in various religious ceremonies. The substance of trust in Subak is not only related to trust in Subak management, but also trust with other stakeholders ( bridging and linking ). Trust between farmers in Subak has been formed for a long period time and has become the main capital of Subak existence. This is due to the process of Subak formation through a complicated process which is preceded by the process of blocking the weir or blocking or sealing in a particular river or channel. Mutual trust can also be seen in irrigation management, namely distribution and allocation of water, management of operations, management of irrigation networks, handling conflicts and implementation of religious ceremonies.

So in line with the paradigm shift in the practice of financial accountability, future research delves deeper into the intrinsic cultural and religious values in the case or area of different financial accountability practices. Thus, in line with the Global Reporting Initiative (GRI) program, that financial reporting contains three things, namely economic, people and planet or triple bottom line can be carried out an in-depth study of intrinsic indicators but can also be measured in financial reporting

\section{Acknowledgements}

This research was supported by Udayana University and Universitas Pendidikan Nasional, Indonesia.

\section{References}

Beckett, R. (2002). Accountability 1000: A new social standard for building sustainability. Communication Ethics Ltd, London, UK.

Bhati, S. S. (2015). Relation between trust theory and agency theory. Commerce and Management - A Modern Perspective, 57-65. Retrieved from http://ro.uow.edu.au/cgi/viewcontent.cgi?article=1792\&context=buspapers

Bovens, M. (2007). Analysing and Assessing Accountability : A Conceptual Framework 1, 13(4), 447-468.

Dewi, N. W. Y. (2008). Akuntabilitas Dalam Bingkai Filosofi Tri Hita Karana: Suatu Eksplorasi Pada Lembaga Perkreditan Desa (LPD) Desa Pakraman Dharmajati Tukadmungga, Kabupaten Klungkung, Propinsi Bali. Thesis. Universitas Brawijaya.

Erikson, E. H. (1968). "Identity: youth and Crisis.” New York, London.

Fikri A. (2010). Studi Fenomenologi Akuntabilitas Non-Governmental Organization WWF (World Wild Fund for Nature). Disertasi Universitas Brawijaya.

Füzér, K. (2016). The social theory of trust and the sociological theory of social capital. Belvedere Meridionale, 28(1), 132-139. https://doi.org/10.14232/belv.2016.1.9

Gambatta, D. (1988). "Can we Trust.” In D. Gambatta (ed) Trust making and breaking cooperative.

Garfinkel, H. (1967). Studies in Ethnometodology. Wiley Blackwel.

Glover, J. (1994). "Profiting through trust”, International Management pp. 38-40 September.

Golofshani, N. (2003). Understanding reliability and validity in qualitative research. The Qualitative Report, 8(4), 597-607. https://doi.org/10.4135/9781412985659

Grafton, R. Q. (2005). Social capital and fisheries governance. Ocean \& Coastal Management, 48(9), 753-766.

Guo, Z. Y. (2017). Credit Constraint Exports in Countries with Different Degree of Contact Enforcement. Business and Economic Research, 7(1).

Halpern, D. (2005). Social Capital. Polity Press.

John, R., \& Scapens, R. (1985). Accounting Systems And Systems Of Accountability-Understanding Accounting Practices In Their Organisational Contexts. Accountitzg Organizations and So\&1.), IO(4). 443-456, 1985.

Kardi, C., \& I. G. A. G. Eka Martiningsih. (2005). Profil Metafisik Pertanian di Daerah Wisata Kabupaten Gianyar. LPPM Unmas: Denpasar.

Koentjoro. (2010), Metodologi Penelitian Kualitatif. Penerbit Salemba Humanika Kovach.

Koppel, J. G. (2005). Pathologies of Accountability: ICANN and the Challenge of Multiple Accountabilities Disorder." Public Administration Review.

Lewandowski, J. (2006). Capitalising Sociability: Rethinking the Theory of Social Capital. In, Assessing Social 
Capital: Concepts, Policy and Practice. R. Edwards, J. Frankin and J. Holland. (eds.) Cambridge Scholars Press.

Lüdeke-freund, F., \& Hansen, E. G. (2011). Business Cases for Sustainability and the Role of Business Model Innovation: Developing a Conceptual Framework Business cases for sustainability: the role of business model innovation for corporate sustainability Stefan Schaltegger *, (July).

Muhajir, N. (2000). Metode Penelitian Kualitatif. Edisi IV. Penerbit Rakesarasin, Yogyakarta.

Neuman, S. (1986). Religious Observance within a Human Capital Framework: Theory and Application. Applied Economics, 18, 1193-1202

Neuman, W. L. (1997). Social Research Methods: Qualitative and Quantitative Approaches (3rd ed.). Boston, MA: Allyn and Bacon.

Nunkoo, R. (2017). Governance and sustainable tourism: What is the role of trust, power and social capital? Journal of Destination Marketing and Management, 6(4), 277-285. https://doi.org/10.1016/j.jdmm.2017.10.003

Nyoman, S. (1983). Subak, Sistem Irigasi Tradisional di Bali. Upada Sastra, Denpasar.

Olsen, W. (2008). Triangulation in Social Research: Qualitative and Quantitative Methods Can Really Be Mixed. Forthcoming as a Chapter in Developments in Sociology, 51(10-12), 732. https://doi.org/10.1016/j.newar.2008.03.024

Ottinger, D. R. T. (1968). Maternal Food Restriction : Effects on Offspring Behavior and Development, 9(1), 7-9.

Perara, M. H. B., \& Matthew M. R. (1996), Accounting theory and Development Australia. International Thomson Publishing Company.

Putnam, R. D. (1993). Making democracy work: Civic traditions in modern Italy. Princeton University Press.

Randa, F. (2011). Rekonstruksi Konsep Akuntablititas Organisasi Gereja (Studi Etnografi Kritis Kulturatif pada Gereja Katolik di Tanah Toraja. Disertasi Universitas Brawijaya.

Saputra, K. A. K, Anggiriawan, P. B., \& Sutapa, I. N. (2018). Akuntabilitas Pengelolaan Keuangan Desa dalam Perspektif Budaya Tri Hita Karana. Jurnal Riset Akuntansi dan Bisnis Airlangga, 3(1).

Shamsuddin, A., Ibrahim, M. I., \& Ridzwan, I. U. B. (2016). The Impacts of Spiritual Capital Towards Corporate Governance Practices: A Case Study of The Government Linked Companies (GLCS) In Malaysia. International Journal of Business, Economics and Law, 9(5) (Apr.) ISSN 2289-1552.

Sirtha, N. (2008), Subak, Konsep Pertanian Religius, Perspektif Hukum, Budaya dan Agama Dharma. Penerbit Paramita Surabay.

Sutha, I. G. K. (1978). Meninjau PerSubakan di Bali. Biro Dokumentasi dan Publikasi Hukum Fakultas Hukum dan Pengetahuan Masyarakat Universitas Udayana Denpasar.

Tenaya, G. A. I. (2007). Analisis Falsafah dan Konsep Akuntansi dalam Perspektif Filsafat Kultur Bali Tri Hita Karana dan Kesadaran Internal Lembaga terhadap Hukum Perusahaan. Tesis. Program Pascasarjana Universitas Brawijaya, Malang.

Triyuwono, (2010). Studi Fenomenologi Akuntabilitas Non-Governmental Organization. Simposium Nasional Akuntansi (SNA) 13. Purwokerto.

Triyuwono, I. (2009). Perspektif, metodologi, dan Teori Akuntansi Syariah. Rajawali Pers. Jakarta.

Vamosi, T. (2005). Management Accounting and Accountability in a new reality of everyday life. The British Accounting review.

Windia, W., \& Dewi, R. K. (2011). Analisis Bisnis Berlandaskan Tri Hita Karana. Udayana University Press. Denpasar Bali.

Woolkock, M., \& Narayan, D. (2002). Social Capital: Implications for Development theory and policy. The World Bank Research Observer, 15(2), 225-249. https://doi.org/10.1093/wbro/15.2.225

\section{Copyrights}

Copyright for this article is retained by the author(s), with first publication rights granted to the journal.

This is an open-access article distributed under the terms and conditions of the Creative Commons Attribution license (http://creativecommons.org/licenses/by/4.0/). 